\title{
Legal nature, contents, and problems of applying a corporate agreement
}

\author{
Anatoly Nikolaevich Levushkin ${ }^{1 *}$, Marina Nikolaevna Ilyushina $^{2}$, Sergey Yurievich \\ Morozov $^{1}$, Aleksander Viktorovich Volkov ${ }^{1}$, and Kama Klimentievna Dzhindzholiya ${ }^{3}$ \\ ${ }^{1}$ Ulyanovsk State University, Department of Civil and Business Law, Ulyanovsk, Russia \\ ${ }^{2}$ All-Russian State University of Justice (Russian Law Academy of the Ministry of Justice of Russia), \\ Department of Civil and Business Law, Moscow, Russia \\ ${ }^{3}$ Kutafin Moscow State Law University (MSAL), Department of Business and Corporate Law, \\ Moscow, Russia
}

\begin{abstract}
A corporate agreement is widely known as a legal structure that allows regulating legal relations and distributing risks between participants in an investment transaction. The establishment of this institution in Russian legislation has opened up great opportunities for both financial and strategic investors. When concluding a corporate agreement with third parties, a "quasi-corporate" agreement is concluded. Study objective: legal research of the current legislation and theoretical concepts regarding the definition of the legal nature, content, and problems of applying a corporate agreement and identification of the most significant proposals for legislation improvement. Methods. The authors of the study applied general scientific and specific scientific methods of research work. In particular, the dialectical method of scientific knowledge, systemic, functional, deduction, induction, analysis, synthesis methods as well as special legal ones like formal legal, comparative-legal, the method of legal modeling, and others were implemented. Results and novelty. The analysis of law enforcement practice showed that, despite a wide selection of both named and unnamed protection measures, none of them guarantee the proper performance of obligations arising from a corporate agreement. This thesis follows from the materials of judicial and arbitration practice.
\end{abstract}

Keywords: corporate legal relations, corporate agreement, corporate governance, legal entity, business entity, obligations

\section{Introduction}

The reform of civil legislation affected the basic institutions of civil law. At the same time, the main trends in the development of public relations, which are the subject of regulation of civil legislation [1] were considered. The agreement is one of the main regulators of civil, business, corporate, and other public relations that develop between business entities [2]. A corporate agreement is an effective tool for achieving a balance of interests of all participants who have concluded it since the parties have the opportunity to foresee possible conflict situations in advance and determine the rules of behavior if they arise [3]. As a result of the

*Corresponding author: lewuskin@ mail.ru 
study, the most essential provisions and conclusions, which are aimed at the effective application of the corporate agreement were identified. An increase in the number of dispositive rules introduced by the legislator to regulate intercorporate relations required the creation of a certain internal structure of local acts [4].

In law enforcement, individual results of the reform aimed at the application of special agreements are obvious [5]. In the literature, the problem of an agreement in the field of entrepreneurship is mainly considered from the standpoint of the interests of entrepreneurs as participants in the relevant agreements, which is quite understandable [6, p. 38]. The institution of the corporate agreement became known to the Russian legal order relatively recently. Namely, the Federal Law of May 05, 20146 No. 99-FZ "On Amending Chapter 4 of Part One of the Civil Code of the Russian Federation and on invalidating certain provisions of legislative acts of the Russian Federation" introduced the general rule on a corporate agreement into the Civil Code of the Russian Federation (hereinafter - the Civil Code of the Russian Federation) (Article 67.2 of the Civil Code of the Russian Federation). If we turn to the experience of foreign legal orders, then in the Anglo-Saxon legal family there is no special legal regulation concerning the structure of a corporate agreement. In this regard, there are no special restrictions in English law on the participation of third parties in a corporate agreement.

Corporate agreements can only be concluded with members of the corporation, and agreements with the participation of other persons are quasi-corporate agreements $[7$, p. 60; $8]$.

\section{Results}

Two methods of legal regulation should be applied simultaneously to corporate governance relations [9]. Despite all the advantages of introducing the institution of a corporate agreement with the participation of third parties, the scientific community expresses quite a lot of doubts about unresolved issues, including those about the consequences of using this legal institution. It seems reasonable for the parties to an investment transaction to immediately conclude a corporate agreement or provide conditions that allow, upon the occurrence of certain events, to re-qualify a "quasi-corporate" agreement into a corporate one.

As follows from the definition, a corporate agreement is a tool for regulating corporate relations between participants in business entities. At the same time, this unique legal instrument allows its participants to explicitly or covertly influence the activities of the society, which allows them to influence decision-making on key and significant issues, as well as control the development of the society itself.

The widespread use of the institution of corporate agreement in Russian practice is associated, first of all, with the rapid development of the technological market, which requires attracting investment. However, the variety of approaches and opinions to the legal nature and content of the institution of a corporate agreement ("quasi-corporate" agreement) deserves special attention. So, one should join the opinion expressed in the doctrine of L.Y. Mikheeva, who characterizes the multidimensionality of the institution of a corporate agreement very concisely: "a corporate agreement is an agreement about anything, and its content is infinite" [10].

\section{Discussion}

In the literature, the problem of an agreement in the field of entrepreneurship is mainly considered from the standpoint of the interests of entrepreneurs as participants in the relevant 
agreements, which is quite understandable [6, p. 38]. Filippova, like many other legal scholars, considers the structure of a corporate agreement, to which the rules of law of obligations must be applied [11]. Courts have repeatedly drawn attention to the fact that business entities independently and at their discretion choose ways to achieve results of entrepreneurial activity [12].

As confirmation of the demand among the participants in the civil turnover of the "quasicorporate" agreement structure, one can cite the statement of I. Shitkina: "according to a "quasi-corporate" agreement, creditors, investors, other third parties, due to the waiver of shareholders of their corporate rights (full or partial) can gain control over a business company to ensure the legally protected interest of such third parties" [13].

A different point of view is held by E.A. Sukhanov: "we are essentially talking about the legislative consolidation of the possibility of withdrawing corporate governance outside corporations" [14]. It should be noted that many researchers adhere to categorical judgments concerning "quasi-corporate" agreements that provide for the ability of third parties to significantly influence the activities of the company: approval of major transactions, change in activities, reorganization of the company. Third parties endowed with the scope of powers in relation to the company are designated as "quasi-participants" since the legal relations between them and the participants of the company "do not lose the essence of corporate relations" [15].

It seems that the members of the company are upfront free in the exercise of their corporate rights, as well as in their choice of concluding a corporate agreement with the participation of third parties if this does not conflict with the company interests.

If we talk about the rules on the automatic performance of obligations from corporate agreements, then not only the Civil Code of the Russian Federation, containing general rules on obligations and agreements, but also special laws on legal entities need to be changed, as they enshrine the features of the performance of obligations from corporate agreements [16].

When concluding a corporate agreement with members of a non-public company, the investor should take into account that information on the content of other corporate agreements is not subject to disclosure and is confidential. Moreover, an investor who did not participate in the signing of a corporate agreement or who entered the company after its conclusion may be in the dark about important information on the management of the company [17]. The solution to this problem can be the construction of an adhesion contract. The parties agree with similar terms and conditions as in the current corporate agreement, where one of the parties will indicate the investor as a potential buyer of the share (shares) in the company. This mechanism presupposes an event upon the occurrence of which the contract is reclassified into a corporate agreement. This moment is associated with the conversion of the amount of debt under the loan agreement into shares (shares) of the company. So, for example, in the American legal order, the terms of conversion are standardized and are carried out automatically when the events specified in the contract occur.

There is variability in Russian law enforcement. For example, within the framework of a "quasi-corporate" agreement, the investor may be given the right to choose either to demand from the company's participants to fulfill obligations under the main agreement or to receive a share (stocks). Thus, when concluding a corporate agreement, an investor needs to provide assurances for the members of the company about the absence of already concluded corporate agreements and the absence of contradictions with the concluded agreement.

The subject of the corporate agreement, according to Y.N. Andreeva and Y.P. Praslova, is "the establishment of the procedure for the implementation of existing subjective corporate rights through restrictions, refraining from exercising their corporate rights, imposing activepassive responsibilities to endure such restrictions, to behave in a certain way" [18]. 
Accordingly, the peculiarity of the contents of a corporate agreement is the voluntary restriction of its parties in their corporate rights, for example in the right to participate in the management of the company's affairs; in the right to receive information about the activities of the company; in the right to appeal against decisions of governing bodies; in the right to compensation for losses caused by the company; in the right to challenge the transactions made by the company; in the preemptive right to purchase shares (stocks); etc.

The conclusion of a corporate agreement is aimed at protecting the rights of members of the corporation. The legislator identifies special methods of protection to protect corporate rights. Relations in the field of protection of property rights of the Russian Federation are widely used at the international level [19]. Special corporate methods are the sale of shares in the manner prescribed by law; the transfer of the rights and obligations of buyers of shares to the bearer of a specific right of first redemption and others [20].

Thus, a unique feature of a corporate agreement lies in the opportunity provided to participants in an investment transaction to include a variety of conditions and obligations that the parties undertake for the investment period: the procedure and terms for providing financing to the company; execution of guarantees under a loan agreement with an investor; provision of management accounting data as part of the expansion of information rights for the investor; conditions of transactions with key assets, major transactions and interestedparty transactions; procedure for attracting new investors and additional investments; redistribution of profits from the current activities of the company; the procedure for the sale of the company's property in case of violation of debt repayment obligations; conditions of the redemption of company shares; redemption of shares at an assessed or nominal value; order and mechanism for overcoming deadlocks, etc.

\section{Conclusion}

A corporate agreement has a complex specific legal nature - a synthesis of corporate and obligation principles. This phenomenon provides participants in transactions with the opportunity to use provisions that, on the one hand, do not directly relate to the corporate agreement, while at the same time correspond to the binding nature of the legal relationship. The institution of corporate agreement acquired the greatest development within the American legal order. The majority of American companies are public, so the issue of confidentiality of the content of corporate agreements is more related to closed corporations. In the countries of continental Europe, the charter is the fundamental corporate document. The corporate agreement can only change the rules of a dispositive nature.

The practice of including in the corporate agreement a clause on the limitation of the rights to dispose of shares (stocks) of the company is widespread among the investment project participants. This choice is due to the desire of the parties to maintain corporate control over the joint activities of the company during the investment period. Meanwhile, if the corporate agreement includes conditions that instruct its participants to vote following the instructions of the governing bodies or determine the structure and competence of the company's bodies, then these provisions will be held invalid.

The multiplicity of the subject structure and corporate agreements leads to a multiplication of risks: the accumulation of financial obligations, a decrease in the value of shares (stocks) of the company, which ultimately leads to the loss of management of the company.

If one of the main objectives of a corporate agreement is to regulate corporate relations within the company, between its participants, then the action of the "quasi-corporate" agreement is directed outside the company, to ensure the legally protected interest of third parties. 


\section{References}

1. M.N. Ilyushina, Laws of Russia: Experience, Analysis, Practice, 7, 43 (2016)

2. N. Levushkin, Laws of Russia: Experience, Analysis, Practice, 8, 30-35 (2018)

3. D.R. Feyzrakhmanova, Russian Justice, 12, 12-15 (2020)

4. M.N. Ilyushina, Entrepreneurial Law. Application "Business and Law in Russia and Abroad", 2, 10-14 (2010)

5. N. Levushkin, Actual Problems of Russian Law, 2, 19-26 (2018). https://doi.org/10.17803/1994-1471.2018.87.2.019-026

6. N. Levushkin, Dogovory v predprinimatelskoi deyatelnosti: uchebnik [Business contracts: Textbook] (Prospect, Moscow, 2021)

7. K.O. Osipenko, Dogovor ob osushchestvlenii prav uchastnikov khozyaistvennykh obshchestv v rossiiskom i angliiskom prave [Agreement on the exercise of the rights of participants in business entities in Russian and English law], PhD thesis in Law (Moscow, 2015)

8. D. Biryukov, Economy and Law, 5 (2015)

9. S.Y. Morozov, Bulletin of Perm University. Legal Sciences, 2, 181-191 (2017)

10. L.Y. Mikheeva, Supplement to the "Economy and Law" Journal, 3, 35 (2015)

11. S.Y. Filippova, Supplement to the "Economy and Law" Journal, 5, 10 (2016)

12. A.V. Volkov, Bulletin of Arbitration Practice, 2, 86-94 (2020)

13. I.S. Shitkina, Korporativnoe pravo: uchebnik [Corporate Law: textbook] (Statut, Moscow, 2019)

14. E.A. Sukhanov, Sravnitelnoe korporativnoe pravo [Comparative corporate law] (Statut, Moscow, 2014)

15. V.A. Laptev, Korporativnoe pravo: pravovaya organizatsiya korporativnykh sistem [Corporate law: legal organization of corporate systems] (Prospect, Moscow, 2019). https://doi.org/10.31085/9785392284238-2019-384

16. A.V. Efimov, Journal of Russian Law, 7, 32-64 (2020).

https://doi.org/10.12737/jrl.2020.080

17. E.V. Zubova, Russian Legal Journal, 4, 143-154 (2017)

18. Y.N. Andreev, Y.P. Praslov, Bulletin of the South-West State University, 4, 177-183 (2013)

19. A. Vlasov, A.N. Levushkin, T.E. Rakhmatullin, L.E. Rakhmatullina, Opcion, 19, 721736 (2019)

20. A.N. Levushkin, A.V. Golysheva, Mezhotraslevoi podkhod k pravovomu regulirovaniyu korporativnykh konfliktov $v$ sovremennoi Rossii: teoriya i praktika primeneniya [Intersectoral approach to the legal regulation of corporate conflicts in modern Russia: theory and practice of application], in E3S Web of Conferences, 210, 9 (2020). https://doi.org/10.1051/e3sconf/202021013019 